\title{
Understanding Entrepreneurial Intention of Vocational High School Students in Indonesia
}

\author{
Eko Prasetyo ${ }^{1}$ \\ ${ }^{1}$ Islamic Economic School (STES) Ihya'ulumiddin \\ E-mail: edunomi@gmail.com
}

\begin{abstract}
:
The present study aims to analyze the entrepreneurial intentions (EI) of students by using theory of planed behavior (TPB) as the underlying thinking framework. The role of entrepreneurial attitude (EA) and entrepreneurial self-efficacy (ESE) as mediators also analyzed. 302 students from five vocational high schools in Indonesia were involved as participants. Mediating role of EA and ESE statistically analyzed by followed Hayes (2018.) EI was statistically significant shaped by entrepreneurial personal motivation (EPM), EA, and ESE. EA and ESE were statistically significant as mediators of EPM towards EI. This finding can be used as preliminary diagnosis of entrepreneurship education program in vocational high school in Indonesia. Entrepreneurship teaching should consider that raise EPM is an important aspect for raising EI.
\end{abstract}

Keywords: Entrepreneurial personal motivation, Entrepreneurial attitude, Entrepreneurial selfefficacy, Theory of planed behavior, Vocational school

\section{Introduction}

The tendency of the student's behavior whether a career to be an entrepreneur or work in a company after graduating school can be predicted by understanding their intentions (Ilouga et al., 2014; Scherer et al., 1991). This is in accordance with the basic concept of TPB that a person's behavior can be predicted by understanding intention (Ajzen, 1991). TPB is used by researchers as a basis for predicting students' entrepreneurial behavior (Autio et al., 2001; García-Rodríguez et al., 2017; Iakovleva et al., 2011; Kautonen et al., 2015; Krueger et al., 2000; Liñán and Chen, 2009; Zhang and Cain, 2017).

Base on the TPB, intention is influenced by several antecedents. There are three main antecedents that shape the EI, namely the attitude to behavior (ATE), perceived behavioral control (PBC) and subjective norm (Ajzen, 1991; Al-Jubari et al., 2018; Kautonen et al., 2015;). A person's intention is also influenced by self-efficacy (Bellò et al., 2018; Boyd and Vozikis, 1994; De Vries et al., 1988; Schmutzler et al., 2018). On the other hand, motivation also plays an important role to forms the intentions (Barba-Sánchez and Atienza-Sahuquillo, 2017, 2018; García-Rodríguez et al., 2017; Mahendra et al., 2017; Tyszka et al., 2011).

Understanding the process of forming entrepreneurial intention is important (Bird, 1988; Boyd and Vozikis, 1994; Liñán and Chen, 2009). Understanding students' entrepreneurial intentions provides great benefits for the program of education (Krueger et al., 2000; Liñán et al., 2011). Understanding of students' entrepreneurial intentions can be taken into consideration to formulate relevant educational programs for entrepreneurship (Douglas and Fitzsimmons, 2013). For teachers, understanding students 'entrepreneurial intentions can help them to increase students' potential through better entrepreneurial education (Krueger et al., 2000).

Analyzing student entrepreneurial intention is important for the formulation of education policies (Douglas and Fitzsimmons, 2013). There must be differentiation between someone who wants to be self-employed or became an employee (Douglas and Fitzsimmons, 2013). Teachers can use student entrepreneurial intentions as a diagnostic tool for the improvement process (Krueger et al., 2000). Teachers should improve students' entrepreneurial intentions through increasing student entrepreneurial motivation as antecedent of entrepreneurial intention (García-Rodríguez et al., 2017).

The importance of understanding student entrepreneurial intentions for the entrepreneurship education is the main reason for conducting this research. This research used TPB as a theoretical foundation that supported by the theory of ESE and entrepreneurial personal motivation (EPM). This study examined the effect of EPM to EI through EA and ESE as mediators. 
International Journal for Social Studies

Available at https://pen2print.org/index.php/ijss/
ISSN: 2455-3220

Volume 05 Issue 02

February 2019

\section{Literature Review}

\subsection{Theory of Planed Behavior}

One of theory that focuses on studying intentions is TPB. This theory examines intention as a tool to predict behavior (Ajzen, 1991). Various studies on intentions have been conducted by researchers use TPB as a basis for theory. Researchers applied TPB in various fields of research, including: the field of health (De Vries et al., 1988), the field of education (Liaw, 2004), understood consumer behavior (Dilmperi et al., 2017), and the field of entrepreneurship (Autio et al., 2001; Feola et al., 2017; Kautonen et al., 2015; Liñán et al., 2011; Liñán and Santos, 2007; Santos et al., 2016). In the field of entrepreneurship, TPB was applied in various ways. Some researchers have studied entrepreneurship only with TPB (Autio et al., 2001; Iakovleva et al., 2011; Kautonen et al., 2015; Liñán and Chen, 2009). Several other researchers modified and tested TPB studies with other theories (Al-Jubari et al., 2018; GarcíaRodríguez et al., 2017; Liñán et al., 2011; Santos et al., 2016; Shiri et al., 2017; Solesvik, 2013).

According to the TPB, the main center of study is devoted to intention as important determine of action (Autio et al., 2001) Intention is a high interest in the specific case (Bird, 1988). In the entrepreneurial context, EI can be used to predict the behavior of entrepreneurship during the starting the business (Krueger et al., 2000). EI is someone's intention to open a business independently (Engle et al., 2010). EI is defined as a strong desire to own a business (Zhang and Cain, 2017).

Based on TPB, one of the important antecedents to EI is EA (Al-Jubari et al., 2018; Feola et al., 2017; Liñán and Chen, 2009; Santos et al., 2016). Attitude is an assessment process and perception of behavior before doing an action (Ajzen, 2001). The same object will be perceived differently by different people. This is the real form of attitude. Interpretation of behavior results differences outcomes if different attitudes are built (Ajzen, 2001). For the same role, in the entrepreneurial context, the attitude shows the perception of entrepreneurship. EA is a personal assessment both positive or negative to become an independent person for starting new business (Liñán and Chen, 2009). EA is how far individuals value exam the concept of entrepreneurship as something that is favored (Kautonen et al., 2015). It's mean that EA is a sense of pleasure or unhappiness reflected in someone's to be selfemployment.

\subsection{Entrepreneurial self-efficacy (ESE)}

According to the view of TPB, the concept of ESE is a similar context to perceived behavior control (PBC). This similarity makes ESE is integrated as part of TPB in several previous studies (De Vries et al., 1988; Engle et al., 2010; Zhang and Cain, 2017). The PBC concept is recognized by Ajzen (1991) developed from the selfefficacy (SE) concept of Bandura (1977). PBC$\mathrm{SE}$ are the same concept about the belief in the ability possessed (Ajzen, 2002). PBC-SE have two important similarities, namely both of them have a strong influence on intention to behave, and both concept are equally talk about the perception of the ability and belief (Armitage and Conner, 2001; Conner and Armitage, 1998).

Self-efficacy is related to specific beliefs about the specific abilities of a person (Ajzen, 2002). Selfefficacy as an important antecedent of entrepreneurial intentions (Barbosa et al., 2007; Boyd and Vozikis, 1994; Chen et al., 1998; Kickul et al., 2009; Kickul et al., 2008; McGee et al., 2009; Tiwari et al., 2017). ESE is a specific term that is used to explain beliefs about specific abilities to the field of entrepreneurship. ESE is an individual's belief with the capability to be success for running a new business independently (Boyd and Vozikis, 1994). ESE is a specific belief that a person is able to succeed in carrying out specific tasks as an entrepreneur (Barbosa et al., 2007). Further, Barbosa et al. (2007) stated that there are four types of ESE, namely, opportunity-identification self-efficacy, relationship self-efficacy, managerial self-efficacy, and the tolerance self-efficacy.

\subsection{Entrepreneurial Personal Motivation}

Human behavior is the result of the motivation processes and cognitive factors (Shane et al., 2003), The successful of an act is influenced by motivation (Herron and Sapienza, 1992). Associated with entrepreneurship, motivation has an important role that play for running a new business creation. Entrepreneurial motivation is a personal reason that encourages people to choose to be an entrepreneur (Segal et al., 2005). Entrepreneurial motivation is a reason that encourages someone to open a business independently (Morales-Gualdrón et al., 2009). Entrepreneurial motivation is not only about the reason, but also the goal and tendency that drives efforts to establish and start a business

There are several motives that influence a person's decision whether to become a worker or an entrepreneur. Previous researchers (MoralesGualdrón et al., 2009) examined multi-dimensional motivation (personal motivation, social environment, organizational environment, business opportunities and scientific development) to become entrepreneur. 


\section{International Journal for Social Studies}

Available at https://pen2print.org/index.php/ijss/
ISSN: 2455-3220

Volume 05 Issue 02

February 2019
Examining multi-dimensional motivation in two different groups also has been done previously by Autio and Kauranen (1994). The first group was an entrepreneur in the field of technology, and the second one was the researchers. There were four dimensions that was examined, namely the factor of opportunity, personal motivation, market pull and technology development In the context of present research, personal motivation from Autio and Kaunen (1994) was used as a reference in the development of motivational instruments. Entrepreneurial personal motivation is specific terms that used in present research closely related to personal reasons that exist in someone who encourages people to become an entrepreneur. Referring to Autio and Kauranen (1994), entrepreneurial personal motivation consists of achievement motive, reasons for selfdevelopment, motivation to be more independent, economic motives and frustration with circumstances.

\subsection{Hypothesis development}

Research findings indicated that there was a significant influence of EA on EI (Liñán and Chen, 2009) This result was also strengthened by several presently researchers (Al-Jubari et al., 2018; Kautonen et al., 2015; Mahendra et al., 2017; Shiri et al., 2017). Wider testing was carried out by Iakovleva et al. (2011) involved 2.235 students from 13 countries. The results of the research showed that EA was the strongest influence on EI when compared with other variables (Iakovleva et al., 2011).

Self-efficacy has a significant effect on decisions (intentions) to become entrepreneurs (Chen et al., 1998; McGee et al., 2009; Wilson et al., 2007) Some recent findings also showed that it was not much different from previous (Bellò et al., 2018; Gupta et al., 2018; Schmutzler et al., 2018; Tiwari et al., 2017; Zhang and Cain, 2017). ESE is an important factor that will directly affect EI (Krueger et al., 2000). Self-efficacy does not only directly affect Intention, but also towards behavior (De Vries et al., 1988). In the context of entrepreneurship, ESE is an important form of EI to build confidence in entrepreneurs, so that they have the courage to act differently and cannot be predicted in the face of uncertainty (Baum and Locke, 2004). The higher the ESE, the stronger the entrepreneurial intention (Boyd and Vozikis, 1994; Chen et al., 1998; Kickul et al., 2008; Wilson et al., 2007).

In the other hand, entrepreneurial motivation has a significant influence on entrepreneurial intention (Barba-Sánchez and Atienza-Sahuquillo, 2017, 2018; Mahendra et al., 2017). The higher entrepreneurial motivation is owned by someone with a high intention towards entrepreneurship. The workers have lower entrepreneurial motivation than the entrepreneur, so that the EI of workers also lower (Tyszka et al., 2011). Motivation provides a real influence on a willingness to do anything for successful in a business (Barba-Sánchez and Atienza-Sahuquillo, 2017). Entrepreneurial motivation to ESE gives a positive and significant influence (Yi and Duval-Couetil, 2018). In the context of a slightly different, achievement motivation has a strong effect on ESE (Scherer et al., 1991). A logical argument can be presented that the higher a person's motivation, naturally will build strong self-confidence and belief that able to complete the tasks and responsibilities as an entrepreneur. This means that entrepreneurial personal motivation in various dimensions will have a significant effect on ESE. Entrepreneurial motivation to attitude has a significant and positive effect (Mahendra et al., 2017). Entrepreneurial motivation had tested to EA, SN and PBC, the result showed the only entrepreneurial motivation-EA has a significant effect (García-Rodríguez et al., 2017). The other tests were shown findings that motivation have a significant effect on attitudes (Solesvik, 2013). In the entrepreneurial context, high entrepreneurial personal motivation can provide a better attitude towards entrepreneurship.

The mediator function EA has been tested by several researchers (Al-Jubari et al., 2018; GarcíaRodríguez et al., 2017; Solesvik, 2013; Zhang and Cain, 2017). Entrepreneurial attitude is a full mediator in the relationship between risk taking and entrepreneurial intention (Zhang and Cain, 2017). Human motivation based on self-determinant theory indirectly influence on EI, with EA, SN and PBC as mediators (Al-Jubari et al., 2018). Regarding entrepreneurial personal motivation, entrepreneurial attitude can act as a full mediator of EI (Solesvik, 2013).

ESE is an important variable that can be a mediator of EI (Bellò et al., 2018). Several tests have been carried out successfully on the role of ESE mediators on EI (Prabhu et al., 2012; Zhang and Cain, 2017; Zhao et al., 2005). In the context of the relationship between EPM and EI, which places ESE as a mediator give strong evident (Yi and DuvalCouetil, 2018). On the other hand, Hui-Chen et al. (2014) stated that there was a positive and significant relationship between motivation and EI, both directly and indirectly. This opinion confirms that EPM towards EI could be mediated by various variables. In the context of present research, EA and ESE could be mediator for EPM toward EI. 
International Journal for Social Studies

Available at https://pen2print.org/index.php/ijss/

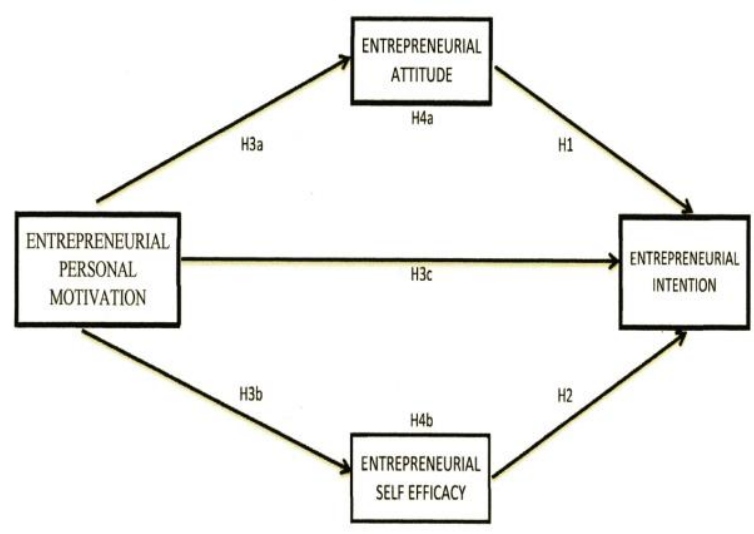

Figure 1. Research framework

Figure 1 show the conceptual frame work of the present research. Base on the figure 1 we can see the relationship between various variable. The hypothesis can be concluded as follows:

$\mathrm{H} 1$ : EA has a significant and positive effect on EI

$\mathrm{H} 2$ : ESE influences the significance and positivity of EI

H3 : EPM has a significant and positive effect on: (a) EA, (b) ESE, and (c) EI

H4 : EPM towards EI indirectly influences significance through (a) EA and (b) ESE as mediator

\section{Research Methods}

The design of this study was compiled by following correlational research rules. The present study aims to examine mediator role of EA and ESE. Hypotheses testing of parallel multiple mediation using direction from the bootstrap technique for estimate the effect of variable (Hayes, 2009, 2018; Preacher and Hayes, 2008). Multiple regression and simple linear regression were used to test hypotheses (Autio et al., 2001; Bellò et al., 2018) All analyzes was carried out with SPSS 22 with Process 3.1 (see, Hayes, 2018). $\mathrm{H}_{0}$ rejected if there is no zero between lower and upper level of confidence interval (Hayes, 2009, 2018; Preacher and Hayes, 2008).

The participants of this research were vocational high school students from 5 schools in East Java Province of Indonesia. All of the schools are public school. 302 students participated voluntary in the present study. 57 students from SMK Negeri Tempursari, Lumajang District, 32 students from SMK Negeri 1 Kraksaan, Probolinggo District, 95 Students from SMK Negeri 2 Tuban, Tuban District, 75 students from SMK Negeri 1 Boyolangu,
Tulungagung District, and 43 students from SMK Negeri 1 Turen, Malang District. All participants were majoring in online marketing program. Age range of respondents was 16-19 years old. $7 \%$ of students were 16 years old, $39 \%$ of students were 17 years old, $42 \%$ of students were 18 years old, and $12 \%$ of students were 19 years old. $72 \%$ respondents were female students. Data collected using questionnaires. The data collection process was carried out for two weeks in the first and second weeks of April 2018. Students was collected in class, they fill the questionnaire voluntarily. The students filled out the questionnaire when they toke entrepreneurship lessons. The filling of questionnaires was supervised directly by entrepreneurship subject teachers.

Development of research instruments was carried out by referring to instruments that had been developed by previous researchers. EA was developed by adapting from Liñán and Chen (2009). EPM was developed by adapting the instruments developed by Autio and Kauranen (1994). ESE instruments refer to instances developed by Kickul et al. (2009). While the EI variable refers to Liñan and Chen (2009). The measurement of the instrument was done by using the Likert scale, from1 to 5 . Value 1 to indicate that it was very disagreeable and the value 5 to indicate that was the quote strongly agrees. To check the internal consistency of the instrument used reliability testing (Scherer et al., 1991). This aims to found out the relevance of instruments in the context of Indonesian culture. The test results showed that EPM had a Cranach's alpha coefficient value of 0 . 817. EA had a Cranach's alpha coefficient of 0.816 . ESE had a value of 0.889. EI had Cranach's alpha coefficient of 0,8 . Based on result of reliability test, all of instruments had good reliability.

\section{Result}

There were three regression models in this research. The first model examined the influence of independent variables on mediator variables ((a) the effect of EPM on EA and (b) EPM on ESE). The second model was independent variable toward the dependent variable (EPM against EI). The third model examined the independent variables and mediators towards dependent variable (EPM, EA, and ESE to EI).

Tabel. 1 The regression analyzis results

\begin{tabular}{lcclc}
\hline \multicolumn{1}{c}{ Variable } & $\begin{array}{c}\text { EA } \\
(\beta)\end{array}$ & $\begin{array}{c}\text { ESE } \\
(\beta)\end{array}$ & \multicolumn{1}{c}{$\begin{array}{c}\text { EI } \\
(\beta)\end{array}$} \\
\hline EPM & $0,4627^{*}$ & 0,5547 & $20,3784^{* /}$ & $3_{-}$ \\
& & $*$ & 0.1094 & \\
EA & & & $0.6834^{*}$ & \\
ESE & & & $0.3094^{*}$ & \\
\hline
\end{tabular}


International Journal for Social Studies

Available at https://pen2print.org/index.php/ijss/
ISSN: 2455-3220

Volume 05 Issue 02

February 2019
${ }^{*} \mathrm{p}<0,05 ;{ }^{2}$ Model $2 ;{ }^{3}$ Model 3; R Square: 0, 6079

The results of all models testing show on table 1. The result shows that EPM, EA, and ESE have a significant effect on EI ( $p<0.000)$. R Square value shows 0.6079 . It means that the variables EPM, EA, and ESE have an effect of $60,79 \%$ to EI, while $39,21 \%$ was influenced by other variables. EA has significant effect towards EI, coefficient value of EA to EI is 0, 68. That's means that $\mathrm{H} 1$ is accepted. $\mathrm{H} 2$ also shows that can be accepted. Based on information from table 1, ESE has significant effect towards EI. Coefficient value of ESE to EI is 0, 31 . Based on table 1, EPM towards EI has different result. EPM to EI, without mediator variables (Model 2) shows significant effect. But, if integrated with mediator variables (model 3) has no significant effect. Coefficient value of EPM to EI is 0, 3784 (Model 2) and -0, 1094 (model 3). Model 1 examines the effect of EPM on EA and ESE. Both effect of EPM to EA and ESE show significant results $(p<0,000)$. Coefficient value of EPM to EA is 0,462 and EPM to ESE is 0, 5547. This results shows that $\mathrm{H} 3 \mathrm{a}$ and $\mathrm{H} 3 \mathrm{~b}$ are accepted.

Table 2 shows direct and indirect effect of EPM to EI through EA and ESE. Based on the data presented in table 2, can be seen that hypothesis testing of total indirect effect of EPM towards EI through EA and ESE as mediators is significant. Based on value of lower and upper of CI, there is no zero between lower and upper of CI. This result can be justified that statistically significant. The same results also show for specific indirect effect of EA and ESE also significant. It means that $\mathrm{H} 4 \mathrm{a}$ and $\mathrm{H} 4 \mathrm{~b}$ are received. Table 2 also informs that total indirect effect of EPM to $\mathrm{EI}$ is 0.4878 . Specific indirect effect of EPM toward EI through EA is 0.3162 , through ESE is 0.1716 . For more detail information can be seen in table 2 below.

Table. 2. Direct and Indirect Effect of EI to EM

\begin{tabular}{llllll}
\hline \multicolumn{1}{c}{ Path } & Effect & SE & LLCI & ULCI & P \\
\hline $\begin{array}{l}\text { Total Effect of } \\
\text { EPM on EI }\end{array}$ & $0,38^{*}$ & 0,08 & 0,21 & 0,54 & 0,00 \\
$\begin{array}{l}\text { Direct effect of } \\
\text { EPM on EI }\end{array}$ & $-0,11$ & 0,06 & $-0,23$ & 0,007 & 0,06 \\
$\begin{array}{l}\text { Total Indirect } \\
\text { effect of EPM on }\end{array}$ & $0,48^{*}$ & 0,07 & 0,33 & 0,63 & \\
$\begin{array}{l}\text { EI } \\
\text { Specific indirect } \\
\text { effect of EPM on }\end{array}$ & $0.32^{*}$ & 0.06 & 0.19 & 0.433 & \\
$\begin{array}{l}\text { EI through EA } \\
\text { Specific indirect } \\
\text { effect of EPM on }\end{array}$ & $0.17^{*}$ & 0.04 & 0.098 & 0.25 & \\
EI through ESE & & & & & \\
\hline
\end{tabular}

EI through ESE

\section{3. $* \mathrm{p}<0,05$}

\section{Discussion}

Figure 2 shows the complete model based on hypothesis test. Based on figure 2, there are two different results in testing $\mathrm{H} 3 \mathrm{c}$. The first testing examines EPM towards EI without involve mediator variables (EA and ESE.). The second test involves EPM, EA and ESE together toward EI. The first testing show EPM towards EI is positive and significant, but the second one is contradictory. This result was in line with Solesvik (2013). The difference results show the role of the mediator variable which reduce the direct influence of EPM on EI. So, although there were two different result, but in whole model (integrated mediator variable), there is no effect of EPM to EI. It could be concluded that the $\mathrm{H} 3 \mathrm{c}$ is rejected.

Hypothesis 1 examined the effect of EA towards EI. The result showed that this testing was accepted. Actually, this result was not surprising. Most of all TPB studies with EA as determinants of EI showed consistent results (Al-Jubari et al., 2018; Autio et al., 2001; Feola et al., 2017; Iakovleva et al., 2011; Kautonen et al., 2015; Liñán and Chen, 2009; Liñán and Santos, 2007; Liñán et al., 2011; Santos et al., 2016) EA was the most powerful variable contribution to influenced EI (Al-Jubari et al., 2018; Iakovleva et al., 2011; Liñán et al., 2011). The findings in this study further emphasized the consistency of the EA as antecedent of EI.

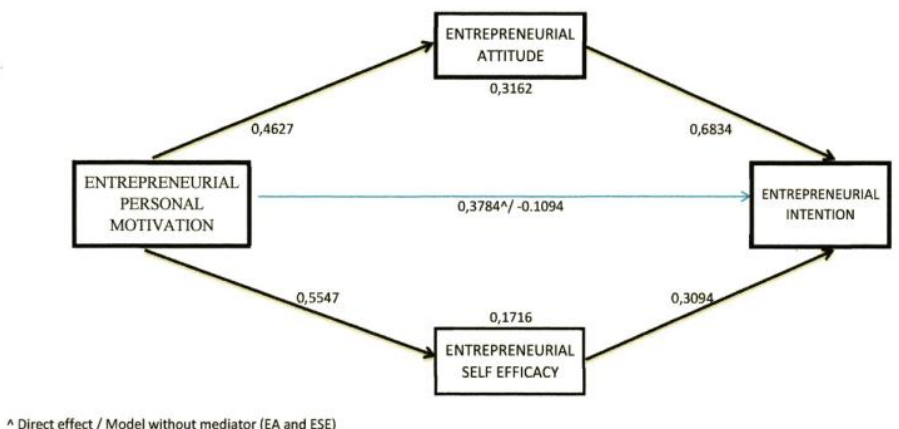

Figure 2. Final result of research analysis

Testing on hypothesis 2 also accepted. This means that ESE had a positive and significant effect on EI. This finding also strengthened several studies that had been carried out previously (Segal et al. 2002; Wang, et al. 2002). The same findings of the research were delivered by Baidi and Suyatno (2018) that in the context of Indonesian cultural setting, ESE had a significant and positive effect on EI. 


\section{International Journal for Social Studies}

Available at https://pen2print.org/index.php/ijss/
ISSN: 2455-3220

Volume 05 Issue 02

February 2019
ESE is an important element for the formation of EI (Boyd and Vozikis, 1994). This was the reason that encouraged the integration of ESE in the EI model (Boyd and Vozikis, 1994; De Vries et al., 1988; Krueger et al., 2000). The results of ESE integration in the EI model that have been done in the present research showed satisfactory results, that ESE had a significant and positive effect on EI. Other research findings also showed great effect of ESE toward EI (Barbosa et al., 2007; Bellò et al., 2018; Chen et al., 1998; Kickul et al., 2009, 2008; Wilson et al., 2007; Zhao et al., 2005). Various results of the research were strengthened by the results of the present research.

The testing results in hypothesis $3 \mathrm{a}$ was in line with previous studies (García-Rodríguez et al., 2017; Mahendra et al., 2017; Solesvik, 2013). The three previous studies (García-Rodríguez et al., 2017; Mahendra et al., 2017; Solesvik, 2013) conducted research in the context of university students. Whereas in present research conducted students in vocational high school. Although, the present research had different level of education for the participants, but the testing showed consistent results.

Hypothesis $3 \mathrm{~b}$ stated that EPM had a positive and significant effect on ESE. The results of this test indicated that the hypothesis $3 b$ could be accepted. This study confirmed that EPM had a significant and positive effect on ESE. This meant that the stronger entrepreneurial motivation made, the greater the confidence to succeed in running a business. These results confirmed the research assumption that ESE and PBC had same context. This could be seen from Solesvik's findings (2013) that entrepreneurial motivation affected PBC. In the context of this research EPM had an effect on ESE.

The result testing of hypothesis $4 \mathrm{a}$ was in line with previous research findings (Solesvik, 2013). Entrepreneurial attitude was a mediator for entrepreneurial personal motivation towards entrepreneurial intention (Solesvik, 2013). The other study conducted also showed that entrepreneurial attitude was able to become a mediator for entrepreneurial intention (Zhang and Cain, 2017). Presently finding showed that EA was a mediator for entrepreneurial intention from antecedent of entrepreneurial intention (Al-Jubari et al., 2018). Based on table 2, specific indirect effect of EPM to EI through EA is significant. The results show that there is no zero on range of LLCI to ULCI. It's mean that statistically significant. Coefficient value of specific indirect effect of EA is 0,316 .
Hypothesis $4 \mathrm{~b}$ states that ESE was a mediator of EPM towards EI significance. The test results based on table 2 shows that the $5 b$ hypothesis can be accepted. There is no zero between LLCI and ULCI. This indicates that ESE is as a mediator of EPM towards EI statistically significant. Coefficient value of specific indirect effect of ESE is 0,172. Identical test results were shown by Solesvik (2013), that ESE (PBC) was a mediator of entrepreneurial motivation towards EI. The other finding also confirmed that ESE was a mediator of EPM toward EI (Yi and Duval-Couetil, 2018). The ability of ESE as a mediator of EI had also been demonstrated by several previous researchers (Bellò, et al 2018; Zhang and Cain, 2017; Zhao et al., 2005). The present research found that ESE was a mediator for EPM towards EI.

\section{Conclusion}

Most of hypotheses testing show satisfying results. Role of ESE as mediator of EPM towards EI is an original finding in this study. The results could provide input for all parties that if you want to build your entrepreneurial generation, you should build variables that affect the intention the implemented entrepreneurial education in schools should be more focus on improving the ESE, EPM and EA students. The higher these three variables, the higher their EI will be. The main limitation in this study is related to the selection of samples in only five schools. Expansion of samples with different contexts is expected to be carried out by other researchers as an improvement effort and get a more comprehensive picture.

\section{References}

Ajzen, I. (1991), 'The theory of planned behavior', Orgnizational Behavior and Human Decision Processes, Vol. 50 No.2, pp. 179-211.

Ajzen, I. (2001), 'Nature and operation of attitudes', Annual Review of Psychology, Vol. 52 No. 1, pp. $27-58$.

Ajzen, I. (2002), 'Perceived behavioral control, selfefficacy, locus of control, and the theory of planned behavior', Journal of Applied Social Psychology, Vol. 32 No. 4, pp. 665-683.

Al-Jubari, I., Hassan, A. and Liñán, F. (2018), 'Entrepreneurial intention among university students in Malaysia: integrating self-determination theory and the theory of planned behavior', International Entrepreneurship and Management Journal, doi: 10.1007/s11365-018-0529-0.

Armitage, C. J. and Conner, M. (2001), 'Efficacy of the theory of planned behaviour: a meta-analytic review', The British Journal of Social Psychology, Vol 40 No. 4, pp. 471-499.

Autio, E., Keeley, R. H., Klofsten, M., Parker, G. G. C., 


\section{International Journal for Social Studies}

Available at https://pen2print.org/index.php/ijss/
ISSN: 2455-3220

Volume 05 Issue 02

February 2019 and Hay, M. (2001), 'Entrepreneurial intent among students in scandinavia and in the USA', Enterprise and Innovation Management Studies, Vol. 2 No. 2, pp. $145-160$.

Autio, E. and Kauranen, I. (1994), 'Technologistentrepreneurs versus non-entrepreneurial technologists: analysis of motivational triggering factors', Entrepreneurship and Regional Development, Vol. 6 No. 4, pp. 315-328.

Bandura, A. (1977), 'Self-efficacy: toward a unifying theory of behavioral change', Psychological Review, Vol. 84 No. 2, pp. 191-215.

Baidi and Suyatno (2018), 'Effect of entrepreneurship education, self efficacy and need for achievement toward students, entrepreneurship intention: case study in FEBI, IAIN Surakarta, Indonesia', Journal of Entrepreneurship Education, Vol. 21, No. 2, pp. $1-16$. Available

at: http://search.ebscohost.com/login.aspx?direct=truea nddb=buhand $A N=77924303$ andsite $=$ ehost-live (accessed: 8/1/2018)

Barba-Sánchez, V. and Atienza-Sahuquillo, C. (2017), 'Entrepreneurial motivation and self-employment: evidence from expectancy theory', International Entrepreneurship and Management Journal, Vol. 13 No. 4, pp. 1097-1115.

Barba-Sánchez, V. and Atienza-Sahuquillo, C. (2018), 'Entrepreneurial intention among engineering students: the role of entrepreneurship education', European Research on Management and Business Economics. No. 24 No. 1, pp. 53-61.

Barbosa, S. D., Gerhardt, M. W. and Kickul, J. R. (2007), 'The role of cognitive style and risk preference on entrepreneurial self-efficacy and entrepreneurial intentions', Journal of Leadership and Organizational Studies, Vol. 13 No. 4, pp. 86-104.

Bellò, B., Mattana, V. and Loi, M. (2018), 'The power of peers: a new look at the impact of creativity, social context and self-efficacy on entrepreneurial intentions', International Journal of Entrepreneurial Behaviour and Research, Vol. 24 No. 1, pp. 214233.

Bird, B. (1988), 'Implementing entrepreneurial Idea: the case for intention', Academy of Management Review, Vol. 13 No.3, pp. 442-453.

Boyd, N. G. and Vozikis, G. S. (1994), 'The influence of self-efficacy on the development of entrepreneurial intentions and actions', Entrepreneurship Theory and Practice, Vol. 18 No. 4, pp. 63-77.

Chen, C. C., Greene, P. G. and Crick, A. (1998), 'Does entrepreneurial self-efficacy distinguish entrepreneurs from managers?', Journal of Business Venturing, Vol. 13 No. 4, pp. 295-316.

Conner, M. and Armitage, C. J. (1998), 'Extending the theory of planned behavior: a review and avenues for further researchln', Journal of Applied Social Psychology, Vol. 28 No. 15, pp. 1429-1464.

De Vries, H., Kijkstra, M. and Kuhlman, P. (1988), 'Selfefficacy: the triad factor resides attitude and subjective norm as a predictor of behavioral intentions.', Health Education Research, Vol. 3 No. 3, pp. 273-282.
Dilmperi, A., King, T. and Dennis, C. (2017), 'Toward a framework for identifying attitudes and intentions to music acquisition from legal and illegal channels', Psychology and Marketing, Vol. 34 No. 4, pp. 428447.

Douglas, E. and Fitzsimmons, J. (2012), "Intrapreneurial intentions versus entrepreneurial intentions: distinct constructs with different antecedents", Small Business Economics, Vol. 41 No. 1, pp. 115-132.

Engle, R.L., Dimitriadi, N., Gavidia, J.V., Schlaegel, C., Delanoe, S., Alvarado, I., He, X., Buame, S. and Wolff, B. (2010), 'Entrepreneurial intent: a twelvecountry evaluation of Ajzen's model of planned behavior', International Journal of Entrepreneurial Behaviour and Research, Vol. 16 No. 1, pp. 35-57.

Feola, R., Vesci, M., Botti, A., and Parente, R. (2017), 'The determinants of entrepreneurial intention of young researchers: combining the theory of planned behavior with the triple helix model', Journal of Small Business Management, doi: $10.1111 / \mathrm{jsbm} .12361$

García-Rodríguez, F. J., Gil-Soto, E., Ruiz-Rosa, I., and Gutiérrez-Taño, D. (2017), 'Entrepreneurial process in peripheral regions: the role of motivation and culture', European Planning Studies. Vol. 25 No. 11, pp. 2037-2056.

Gupta, P. D., Bhattacharya, S., Sheorey, P., and Coelho, P. (2018), 'Relationship between onboarding experience and turnover intention: intervening role of locus of control and self-efficacy', Industrial and Commercial Training, Vol. 50 No. 2, pp. 61-80.

Hayes, A. F. (2009), 'Beyond Baron and Kenny: statistical mediation analysis in the new millennium', Communication Monographs, Vol. 76, No. 4, pp. 408-420.

Hayes, A. F. (2018), Introduction to Mediation, Moderation, and Conditional Process Analysis. A Regression-based Approach. New York: The Guilford Press.

Herron, L., and Sapienza, H. J. (1992), 'The entrepreneur and the initiation of new venture launch activities', Entrepreneurship Theory and Practice, Vol. 17 No. 1, pp. 49-55.

Iakovleva, T., Kolvereid, L. and Stephan, U. (2011), 'Entrepreneurial intentions in developing and developed countries', Education + Training, Vol. 53 No. 5, pp. 353-370.

Ilouga, S. N., Mouloungni, A. C. N. and Sahut, J. M. (2014), 'Entrepreneurial intention and career choices: the role of volition', Small Business Economics, Vo;. 42 No. 4, pp. 717-728.

Kautonen, T., Van Gelderen, M. and Fink, M. (2015), 'Robustness of the theory of planned behavior in predicting entrepreneurial intentions and actions', Entrepreneurship Theory and Practiceractice, Vol. 39 No. 3, pp. 655-674.

Kickul, J., Wilson, F., Marlino, D., and Barbosa, S. D. (2008), 'Are misalignments of perceptions and selfefficacy causing gender gaps in entrepreneurial intentions among our nation's teens?', Journal of Small Business and Enterprise Development, Vol. 15 No. 2, pp. 321-335. 
International Journal for Social Studies

Available at https://pen2print.org/index.php/ijss/
ISSN: 2455-3220

Volume 05 Issue 02

February 2019
Kickul, J., Gundry, L. K., Barbosa, S. D., and Whitcanack, L. (2009), 'Intuition versus analysis? testing differential models of cognitive style on entrepreneurial self efficacy and the new venture creation process', Entrepreneurship Theory and Practice, Vol. 33, No. 2, pp. 439-453.

Krueger, N. F., Reilly, M. D. and Carsrud, A. L. (2000), 'Competing models of entrepreneurial intentions', Journal of Business Venturing, Vol. 15 No 5, pp. 411-432.

Liaw, S. S. (2004) 'The theory of planned behaviour applied to search engines as a learning tool', Journal of Computer Assisted Learning, Vol. 20 No. 4, pp. 283-291.

Liñán, F. and Chen, Y. (2009), 'Development and crosscultural application of a specific instrument to measure entrepreneurial intentions', Entrepreneurship Theory and Practice, Vol. 33 No. 3, pp. 593-618.

Liñán, F. and Santos, F. J. (2007), 'Does social capital affect entrepreneurial intentions?', International Advances in Economic Research, Vol. 13 No. 4, pp. 443-453.

Liñán, F., Urbano, D. and Guerrero, M. (2011), 'Regional variations in entrepreneurial cognitions: Start-up intentions of university students in Spain', Entrepreneurship and Regional Development, Vol. 23 No. 3-4, pp. 187-215.

Mahendra, A. M., Djatmika, E. T. and Hermawan, A. (2017), 'The effect of entrepreneurship education on entrepreneurial intention mediated by motivation and attitude among Management Students, State University of Malang, Indonesia', International Education Studies, Vol. 10 No. 9, pp. 61-69.

McGee, J. E, Peterson, M., Mueller, S. L., and Sequeira, J. M. (2009), 'Entrepreneurial self-efficacy: refining the measure', Entrepreneurship Theory and Practice, Vol. 33 No. 4, pp. 965-988.

Morales-Gualdrón, S. T., Gutirreez-Gracia, A. and Dobon, S. R. (2009), 'The entrepreneurial motivation in academia: a multidimensional construct', International Entrepreneurship and Management Journal, Vol. 5 No. 3, pp. 301-317.

Preacher, K. J. and Hayes, A. (2008), 'Asymptotic and resampling strategies for assessing and comparing indirect effects in multiple mediator models', Behavior Research Methods, Vol. 40 No. 3, pp. 879-891.

Santos, F., Roomi, M. A. and Liñán, F. (2016), 'About gender differences and the social environment in the development of entrepreneurial intentions', Journal of Small Business and Management. Vo;. 54 No. 1, pp. 49-66.

Scherer, R. F., Brodzinski, J. D. and Wiebe, F. A. (1991), 'Examining the relationship between personality and entrepreneurial career preference', Entrepreneurship and Regional Development, Vol. 3 No. 2, pp. 195206.

Schmutzler, J., Andonova, V. and Diaz-Serrano, L. (2018), 'How context shapes entrepreneurial self-efficacy as a driver of entrepreneurial intentions: a multilevel approach', Entrepreneurship Theory and Practice, doi: $10.1177 / 1042258717753142$.

Segal, G., Borgia, D. and Schoenfeld, J. (2005), 'The motivation to become an entrepreneur', International Journal of Entrepreneurial Behaviour and Research, Vol 11 No. 1, pp. 42-57.

Shane, S., Locke, E. A. and Collins, C. J. (2003), 'Entrepreneurial motivation', Human Resource Management Review, Vol 13 No. 2, pp. 257-279.

Shiri, N., Shinnar, RS, Mirakzadeh, A. A and Zarafshani, K. (2017), 'Cultural values and entrepreneurial intentions among agriculture students in Iran', International Entrepreneurship and Management Journal. Vol. 13 No. 4, pp. 1157-1179.

Solesvik, M. Z. (2013), 'Entrepreneurial motivations and intentions: Investigating the role of education major', Education + Training, Vol. 55 No 3, pp. 253-271.

Tiwari, P., Bhat, A. K. and Tikoria, J. (2017), 'The role of emotional intelligence and self-efficacy on social entrepreneurial attitudes and social entrepreneurial intentions', Journal of Social Entrepreneurship, Vol. 8 No. 2, pp. 165-185.

Tyszka, T., Cieslik, J., Domurat, A., and Mackoa, A. (2011), 'Motivation, self-efficacy, and risk attitudes among entrepreneurs during transition to a market economy', The Journal of Socio-Economics, Vol 40 No. 2, pp. 124-131.

Wilson, F., Kickul, J. and Marlino, D. (2007), 'Gender, entrepreneurial self-efficacy, and entrepreneurial career intentions: implications for entrepreneurship education', Entrepreneurship Theory and Practice, Vol. 31 No, 3, pp. 387-407.

Yi, S. and Duval-Couetil, N. (2018), 'What drives engineering students to be entrepreneurs? evidence of validity for an entrepreneurial motivation scale', Journal of Enginering Education, Vol. 107 No. 2, pp. 291-317.

Zhang, P. and Cain, K. W. (2017), 'Reassessing the link between risk aversion and entrepreneurial intention: the mediating role of the determinants of planned behavior', International Journal of Entrepreneurial Behaviour and Research, Vol. 23 No. 5, pp. 793811.

Zhao, H., Seibert, S. E. and Hills, G. E. (2005), 'The mediating role of self-efficacy in the development of entrepreneurial intentions', Journal of Applied Psychology, Vol 90 No. 6, pp. 1265-1272. 